\title{
pro.posıções
}

$e$-ISSN 1980-6248

http://dx.doi.org/10.1590/1980-6248-2016-0052

ARTIGOS

\section{The journey of school knowledge in High School and the concept of refraction $^{1}$}

Ivor Goodson (i)

Maria Inês de Freitas Petrucci dos Santos Rosa (ii)

(i) University of Brighton, Brighton, United Kingdom, I.F.Goodson@brighton.ac.uk

(ii) University of Campinas -UNICAMP; Campinas, SP, Brazil, minespetrucci@gmail.com

\begin{abstract}
This paper deals with the journey of school knowledge through different sites from its origin in the curriculum, to professional teachers' life histories. At each site, a set of empirical materials is examined relating to the subject of research. In this sense, curriculum documents, textbooks and high school teachers' narratives were analysed, observing the refractive processes gone through during the journey. The research encompasses the curriculum policies for the Brazilian high school in the last two decades. As a result, it highlights the unexpected ways of appropriation that emerge out of control along the way. Dealing with the reinterpretations of curriculum policies, it is necessary to consider the sensibilities and intentions involved in every state. It is possible to perceive, through a narrative capital, that public policies need to contemplate the life missions of the social actors involved in the education process.

Keywords: school knowledge, narrative, interdisciplinarity, high school
\end{abstract}

...the curriculum provides a prism, a litmus test, through which to see and test societal bealth and character.

(Goodson, 2014, p. 14)

In Brazil, the 1990s were marked mainly by FHC government's ${ }^{2}$ educational policies, which represented an important period of neoliberal change inducing curriculum restructuring in high schools. As a result, high schools have undergone an intense restructuring process

\footnotetext{
${ }^{1}$ Supported by: Coordenação de Aperfeiçoamento de Pessoal de Nível Superior - CAPES, process 2594/15-3.

${ }^{2}$ The sociologist Fernando Henrique Cardoso (FHC) was President of Brazil from 1995 to 2002.
} 


\section{pro.posıções}

$e$-ISSN 1980-6248

http://dx.doi.org/10.1590/1980-6248-2016-0052

since the beginning of the 21st century. Specifically, the notions of skills and abilities surfaced in the curriculum from which the disciplinary matrix had been organised. The National Curriculum Parameters have set out the profile of a new youth worker who deals with school knowledge as a pretext for developing such skills and abilities. Even with the Labour Government assuming power in 2003, there was no break with the previously established curriculum policies (Lopes, 2004), and some of the key aspects of the curriculum documents remained, such as the didactic and methodological axes of interdisciplinarity and contextualisation.

In fact, since the establishment of the National Curriculum Guidelines for Secondary Education (Brasil, 1998), school knowledge organisational principles were traded out for the notion of competence and skills, culminating in the National Curriculum Parameters Document for High Schools (PCNEM). Deepening the approach of such principles is the perceived social purpose of education turning to preparation for work and social practice in a globalised world (Lopes, 2004). "Preparation for life" was touted in the document as having a straight link to the labour market and the need for more young workers who must be eclectic, generalists, and versatile.

Despite the tension between skills and school knowledge, the $\mathrm{PCNEM}^{3}$ reiterates the stability of school subjects (Brasil, 2000). Along with this reaffirmation of disciplinary organisation, the document also points to two didactic and methodological axes: the notions of interdisciplinarity and contextualization. The first one is particularly stimulated by problem situations or broad issues that may encompass different languages and fields of knowledge in building a methodological route to school knowledge production.

However, even though the document was organised by areas, teachers are distinguished by school subjects: the "razor's edge" between knowledge and skills. This perspective was also maintained under the Labour Government with the publication of other official curriculum documents called the Curriculum Orientations for Secondary Education OCEM (Brasil, 2006). In these documents, the notion of skills appears more unstable, being evident in some disciplinary groups but not in others.

\footnotetext{
3 The National Curriculum Parameters for High School (PCNEM) is a curriculum document published by the Ministry of Education in 2000.
} 


\section{pro.posıções}

$e$-ISSN 1980-6248

http://dx.doi.org/10.1590/1980-6248-2016-0052

Concerning these issues, the focus of this paper is situated in the last fifteen years, with particular attention given to refraction processes involving school knowledge inside curriculum policies. This refraction is part of what we call the journey of knowledge, particularly in high school. In other words, we contemplate the restructuring process of neoliberal policies for high schools concerning the pathways of school knowledge.

We consider four elements of the restructuring process and seek to highlight the refractive dynamics that occurred. These items are school knowledge, curriculum, pedagogy and classroom. The journey of school knowledge in high school over the last fifteen years is the route through which these four elements can be defined.

Before we discuss this journey, we need to detail what each element of the process entails. School knowledge is understood as a set of concepts, languages, procedures and practices inside school subjects. In this sense, school knowledge arises within the scope of curricular policy as an active reference mark of teacher identities and highlights the social purposes of the selection of knowledge established in schools. The curriculum, in a broader sense, subsumes the whole set of speeches, documents, stories, and practices that imprint on the identities of individuals involved in the schooling process. With this view, curriculum documents such as $\mathrm{LDB}^{4}$, DCNEM 5 , PCNEM, OCEM, and more recently BNCC 6 are made from systemic narratives that tell how schools produce knowledge.

We call "pedagogy" the movements, actions, and initiatives for the transformation of knowledge into learnable knowledge. Pedagogy includes textbooks, which are important resources organized by disciplines in high school subjects. Finally, we consider the classroom through the professional life narratives of teachers. In the narratives, teachers bring scenes, episodes, dilemmas and dramas around the production of school knowledge in the teaching processes with students and outline each disciplinary field.

\footnotetext{
${ }^{4}$ National Education Guidelines and Framework Law (LDB 9.394/96).

${ }^{5}$ National Curriculum Guidelines for high school (DCNEM, 1998).

${ }^{6}$ The BNCC is the National Common Curricular Basis that is not yet published for high school.
} 


\section{pro.posições \\ $e$-ISSN 1980-6248 \\ Educational change times and refractive standards - a methodological approach}

http://dx.doi.org/10.1590/1980-6248-2016-0052

Lindblad and Goodson (2011) discuss the educational restructuring processes in three different ways: 1) restructuring as a model for organization and rational planning in times of rapid change and instability; 2) restructuring as a consequence of social and political changes within the system, and 3) restructuring as a process that carries an infinite number of possible modes of operation between education and school organization. To understand educational restructuring, the authors define at least two types of narratives. The first is a systemic narrative found in documentary sources of reform and restructuring initiatives in each particular context. The second category is the narrative of professional lives as obtained from interviews with teachers immersed in the school routine. The consideration of these forms of narrative and their potential to become compatible with the third restructuring process were identified by Lindblad and Goodson (2011). The infinite number of possible modes leads to the understanding of the unpredictability, the level of sensitivity, and the full range of meanings that are inherent in these processes.

With this methodological approach, focusing on different historical periods of restructuring becomes important. This historical approach is inspired by the French school of the Annales method. It can identify individuals in different historical periods of restructuring, which Goodson (2014) calls "windows of opportunity". The definition of periods allows us to glimpse the professional possibilities of action, as the professional narratives highlight particular points of historical time.

Such historical trajectories show that restructuring takes place in each context with different angles. Periods and historical trajectory systems can both be seen as refracted restructuring initiatives: "Studying the translation and dissemination give us access to the refraction process" (Goodson, 2014, p. 35).

A large set of professional life narratives evidences the occurrence of historical refraction patterns. Refraction refers to the process by which global standards are re-directed by rearranging them in their historical and cultural contexts. 


\section{pro.posıções}

$e$-ISSN 1980-6248

Just as with the refraction of light through the window, global initiatives that follow similar intentions can end up moving in intended directions and sequences. Whilst in some ways, refraction is similar to the concept of re-contextualisation, the work focuses not only on the external changes in local and professional cultures and in personal contexts, but also on internal. (Goodson, 2014, p. 35)

Rudd and Goodson (2016) develop the concept of refraction proposed in Goodson (2014), Goodson and Rudd (2012) and Rudd and Goodson (2014). They present refraction as a conceptual tool appropriate to research studies regarding educational discourse, systems, policies and practices. In Goodson's words:

This refraction [emphasis in the original] results in global trends being mediated by wider national histories, traditions and dominant ideologies and politics, and national policies being translated through institutional cultures and practice and redirected through actions arising based on individuals' and groups' own beliefs, values and trajectories. ... This complexity requires conceptual and theoretical tools that can support better exploration and investigation, and which can provide richer and contextualised understandings of practice, merely than it being seen as linear or direct responses to change. (Rudd \& Goodson, 2016, p.101)

The concept of refraction requires an understanding that encompasses the simultaneous analysis of "structure and agency" (Rudd \& Goodson, 2016, p.101), while situating processes in their historical contexts. In this sense, it is important to consider that policies are always being reinterpreted and redirected locally, inside classrooms and being reviewed by people. The effects produced by refraction result in the translation or "bending" of policies, as a complex interaction occurs between ideology, structures and both institutional and individual action.

Refraction provides an impressive lens for empirical research that articulates macro, meso and micro levels of educational policies. The micro level is constituted through the analysis of case narratives of professional practice, configuring what Rudd and Goodson (2016) call "episodes of refraction".

As a concept, refraction [emphasis in the original] draws on a range of existing traditions and approaches, but it has at its heart a need to explore action in relation to the dominant waves of reform and the policies introduced in the field, and in particular, in exploring and trying to understand the motivations behind practice that appears at odds with predominant reform waves. (p.101) 


\section{pro.posıções}

$e$-ISSN 1980-6248

http://dx.doi.org/10.1590/1980-6248-2016-0052

Three aspects of refraction are highlighted: 1) the need to place the research in a wider socio-historical context, which is achieved with the methodology of periodisation; 2) the identification of the effects of ideology and power of the policies and their relations on professional practice and teaching identity; 3) the assumption that the ideology and power effects of policies in professional practice are not linear and cannot be understood in a deterministic way.

\section{School knowledge—-the first site of knowledge production}

Since its beginnings, Brazilian high school has been organised into school subjects. The Reform of 1931 is a benchmark in establishing school subjects, many of which have stabilised in the curriculum, such as Portuguese language, Mathematics, History, Geography, Chemistry, and Physics (Zotti, 2004). For Kliebard (quoted by Goodson, 1997, p. 29), the disciplinary curriculum is configured as an "impregnable fortress". School subjects do not express exclusively epistemological spaces, and political and historical communities who share interests and resources recognize themselves as a disciplinary community (Goodson, 1997). A disciplinary community is founded upon the engagement of different social actors who share their struggles for resources, status, and school or academic space. They are professors, primary educators, or researchers who compose a group or disciplinary community from different historical periods (Goodson, 1983, 1997).

However, a disciplinary community can also be a heterogeneous group, made up of internal subgroups that live in antagonism; however, despite the agonistic possibilities, disciplinary communities coexist with a design to maintain stability and promote school subjects. Goodson $(1983,1997)$ highlights the importance of cohesion in the professional identification supported by the school subject, which gives particular importance to disciplinary associations. In this sense, they help students and elementary education professionals, and their shared demands are strengthened in the processes of decision-making under conflict.

Investigating the history of school subjects is a way to clarify their origins and formation processes through the study of trends and changes that have occurred in the selection of content and teaching methods. The study of school subjects should focus on 


\section{pro.posıções}

$e$-ISSN 1980-6248

http://dx.doi.org/10.1590/1980-6248-2016-0052

intentions and implied powers since the interests in some matters can increase status in professional careers. School subjects are constituted by groups of elements: identity, values and different interests. Seeking higher status, teachers are encouraged to "set curricular knowledge in abstract, formal, and academic terms, in exchange for professional development, resources, territoriality and accreditation" (Goodson, 2001, p. 99).

By analysing two subjects—one academic and the other educational— we reach three general conclusions on school subject constitution. First and foremost, school subjects are not monolithic entities, but amalgams of subgroups and traditions influenced by conflicts and disputes that decide what content, methods and goals may or may not be legitimate. Secondly, to become an academic discipline linked to the university, it is necessary to leave utilitarian goals and teaching; and finally, the construction of the curriculum needs to be analysed with reference to a conflict between the school subjects "regarding status, resources, and territory" (Goodson, 2001, p. 120).

The study of school subjects defines some "traditions" that often can be related to the origins of social class and the occupational destination of students. Thus, fundamentally academic curricula were originally intended for students from middle and upper classes to prepare them for professional life, while more practical and pedagogical subjects were deemed appropriate for most other students for vocational training.

Into this scenario, we adopt the notion of tradition proposed by Eric Hobsbawm (1994) regarding academic, practical, and pedagogical traditions. The academic tradition is related to the institutionalisation of external examinations confirming the status of the discipline as a rigid body of knowledge, implying allocation of resources. In this sense, abstract knowledge is intimately tied to teaching geared to the interests of the ruling classes, with teachers trained in specific disciplines. This situation leads to the increase in the number of members of disciplinary communities and the establishment of a good speech to this status hierarchy defining the academic disciplines that are suitable for "capable" students.

The utilitarian tradition is related to the working world, common sense and relevance for social life, comprising commercial and technical education with more practical knowledge but with lower status. Finally, the pedagogical tradition is related to teaching methods and the 


\section{pro.posıções}

$e$-ISSN 1980-6248

http://dx.doi.org/10.1590/1980-6248-2016-0052

learning systems of children. In this tradition, the central concern is to make teachable content and prioritise methods for teaching.

Inside the arena of struggle among the traditions, active social mechanisms operate simultaneously in two intertwined curricular dimensions, resulting in patterns of stability and change: institutional and organisational. The institutional dimension is configured as a valuable currency in the educational market because identifiable and standardizable social typifications are necessary and allow students to build school careers with individual professional and social goals on the horizon. These categories are also important for teachers, who work to ensure a future for their students looking for good careers and professional status.

In this sense, disciplinary spaces take on a mission connected to the educational market through rhetoric, defining identifiable and credible categories for the public eyes. Rhetoric ends up becoming a reality. Most important for the success of school subjects is not exactly delivering "goods" to be evaluated but maintaining legitimate discourse, maybe supporting activity that is properly classified.

The social function of education defines parameters, perspectives and incentives for those involved in the construction of school subjects. The interface between internal disciplinary actors and external relations is always evident in the search for resources and ideological support. Such searches cover two aspects: limiting the action strategies and promoting and facilitating versions and particular views on school subjects.

Regarding the organisational dimension, despite the existence of continuous historical differences between groups and subgroups that influence and dominate the curriculum decisions, disciplinary standards are maintained, supporting disciplines and being sustained by them in the structuring programmes. However, changes may occur at certain levels and domains and may not happen in others, since the groups involved with the activities of discipline are not homogeneous in relation to values, interests, and identities.

In Brazilian high school curriculum management, there are stabilised school subjects such as Portuguese language, History, Geography, Physics, Chemistry, Biology, Mathematics, and Physical Education (Gym). These subjects have long been present in the curriculum, and some of them have gone through a series of developments. They left a first stage of periphery, went through a utilitarian status and finally, reached a definition of school subjects built with a 


\section{pro.posıções}

$e$-ISSN 1980-6248

http://dx.doi.org/10.1590/1980-6248-2016-0052

rigorous set of knowledge. In the last eighty years, based on the Francisco Campos Reform from 1931, the presence of others school subjects oscillated in high school curriculum, including Art, Philosophy, Sociology, Religion and English language.

The factors that interfere with this stability may be classified as internal and external. Internal factors regard labour conditions inside specific areas, such as the arising of different groups of intellectual leadership, the emergence of academic centres of prestige offering professional training, the organisation of professional associations, and the editorial policy in the area. On the other hand, external factors concern the educational system and wider economic, social and politic contexts. Moreira and Ferreira (2001) point out that the strength of all these factors depends on the tradition of the school subject-academic prestige and length of existence- and on its level of organisation. This kind of organisation expresses itself in academic associations and in the educational system structure. This way, it is possible to perceive that the more mature a school subject is, the more relevant the internal factors are. These features increase proportionately to the decentralisation of the educational system. On the other hand, the burden of external factors might be more efficient in countries experiencing rapid transformation processes.

School subjects are not established in the school curriculum peacefully, conforming to the official guidelines; but on the contrary, they maintain agonistic relations with academic theorisations and formal recommendations, sometimes abiding by them, at times resisting them, sometimes reforming them or deforming them.

With these reflections more focused on the relationships between school knowledge, school subject and teaching, we consider that this first site of school knowledge is constituted not only by epistemological dynamics but mainly by socio-cultural processes, as it mobilises identities in the school culture. The nature of the school subject is historical, and school knowledge distinguishes itself with peculiarities that mark its social and political character. Its stability also depends on the path that it will take towards pedagogical practices. It is for this purpose that we continue this journey into the next site, the curriculum, which is understood as the set of systemic narratives present, mainly, in texts known as official curricular documents. 


\section{pro.posıções}

$e$-ISSN 1980-6248

http://dx.doi.org/10.1590/1980-6248-2016-0052

\section{Curriculum documents—-the second site}

To analyse the second site of the journey of school knowledge in high school restructuring, we focus on two documents: the National Curriculum Parameters for Secondary Education - PCNEM (Brasil, 2000) and the National Curriculum Orientations for Secondary Education - OCEM (Brasil, 2006). They were selected because they are linked to the next elements of pedagogy or teaching. Both the Parameters and the Orientations discuss and reflect on work in the classroom, combining the methodological didactic principles, concepts, languages, practices, and values of each disciplinary field. We are interested in understanding this journey of school knowledge through the scope of a school subject. For this, we focus on the systemic narratives presented in the documents. PCNEM (Brasil, 2000) indicates that interdisciplinarity must go beyond the mere juxtaposition of school subjects and, at the same time, avoid diluting them in generalities. The document affirms it is mainly in the possibility of linking the disciplines in activities or study projects, research, and action that interdisciplinarity may be a pedagogical and didactic practice that is appropriate for the goals of high school. Interdisciplinarity, according to this document, is also engaged when subjects that know, teach, and learn are dealing with procedures that in a single disciplinary vision may seem unorthodox, but make sense when used to address complex issues. If it concedes that some artistic procedures may seem like "prophecies" from the scientific perspective, PCNEM suggests that the picture of the resulting mushroom cloud from a nuclear explosion also explains, in a different way from Physics, the meaning of the atomic bomb.

Even though the document has been organised by areas within a continuous appreciation of the idea of integration, it should be noted that teachers are distinguished by school subjects. There is an invitation for more creative dialogues, for example, the integration of knowledge and practices between Physics and Art. However, it is also important to point out that the cases dealt with in PCNEM seem always to be lonely efforts to integrate school subjects in a "pair by pair" mode. Although it is considered as a starting point in this "turnaround" of school knowledge in high school, PCNEM narrates the interdisciplinary issue systematically, without deepening the possibilities and dilemmas proper of the pedagogical practices. 


\section{pro.posıções}

$e$-ISSN 1980-6248

http://dx.doi.org/10.1590/1980-6248-2016-0052

Under the Labour Government in 2003, the Ministry of Education began to worry about curricular policies at various levels, trying to give a differentiated tone to the systemic narratives about the education of children and young people. In these documents, the notion of competence is sporadically discussed, sometimes rebutted, since the texts of the different school subjects were written by the various disciplinary communities without consistent articulations during the elaboration process. About interdisciplinarity, OCEM (Brasil, 2006) points out that a first step that can be productive and subsequently lead to systemic interdisciplinarity is simultaneously approaching the same subject from different disciplines. The document indicates this procedure requires an arrangement of lesson plans and schedules among teachers while respecting the specificities of each school subject. By doing this, OCEM affirms, teachers of different school subjects and areas can discover content to enable joint work. Moreover, this action can lead teachers to perceive how the same concept, process, or phenomenon is approached in different school subjects and to investigate the common grounds that can be explored in class.

The document deals with the notion of interdisciplinarity as shown above. Despite these brief indication, no other considerations about the possibilities of approaching school knowledge in an integrated way is developed.

Thus, considering that the curriculum is a social production, educational policies always seek to "recreate" a school that also meets the demands of the world of work. The systemic narratives in favour of interdisciplinarity oscillate between the preservation of disciplinary boundaries and the assumption of polyvalence. This important issue demonstrates a utilitarian trend in the treatment of school knowledge.

To conclude this section, we note that the systemic narratives of the selected curriculum documents constrain school knowledge into a permanent tension between school subjects and integrated practices. Such tension culminates in ambiguity that approaches contradiction, as it reinforces and enhances specific conceptual frameworks of disciplines while at the same time driving them permanently to dialogue around everyday situations. 


\section{pro.posıções}

$e$-ISSN 1980-6248

http://dx.doi.org/10.1590/1980-6248-2016-0052

\section{Pedagogy — the third site}

In Brazil, forms of teaching school knowledge are specially marked by the presence of textbooks on pedagogical practices. For a decade, the Brazilian government has had a program for acquiring high school textbooks for public schools. This policy began with the National Secondary School Textbook Program (PNLEM) in 2005 under the responsibility of the Secondary School Department, and was later transferred to the National Textbook Program (PNLD) as part of the Basic Education Department in the Ministry of Education. Publishers submit their textbooks for evaluation, and those that are approved are made available for teachers to acquire and use in the classroom. The assessment process of these textbooks is based on public notices that are published each year with specific criteria. On average, 30 million Brazilian students are supported by the PNLD each year.

In this paper, as the third site on this journey, we focus on the systemic narratives presented in the PNLD Public Notices for high school published in the last 15 years regarding the organisation of school knowledge and its consequences for the relationship between subjects and interdisciplinary practices. The Public Notice (Brasil, 2015) understands that education should be developed in context and in an interdisciplinary manner from a curriculum designed based on four areas of knowledge established by the LDB: languages; mathematics; natural sciences; humanities. It also considers important to articulate the curriculum components of the areas and among areas in the development and education of students. In another passage, the Public Notice (Brasil, 2015) affirms that the school subjects have played a major role in the research, the dissemination, and the teaching-learning of specialised knowledge, inasmuch as they allow for the recognition, the understanding and the assimilation of different objects of study: skills and related abilities; predictable ways of working together with other knowledge; the same approach perspective; varying levels of complexity; procedures of analysis with the same nature. The public notice indicates that, on the other hand, training for life in the context of a comprehensive and emancipating education demands a strong link between the proposed objects of study, with the objective of allowing the student to not only recognize and study topics that exceed the homogeneous confines of only one discipline (such as language, the psyche, life in society, natural phenomena, etc.), but also to understand more broadly and to integrate the learning process itself, or even the nature of the production and reproduction of knowledge. 


\section{pro.posıções}

$e$-ISSN 1980-6248

http://dx.doi.org/10.1590/1980-6248-2016-0052

Systemic narratives in this curriculum document mark the permanence of the same tension perceived in the previous site, legitimising the recognition of school knowledge organisation in academic fields. However, the demands on the interdisciplinary practices are justified in "education for life", which should be linked to an integrated understanding of knowledge production. This perspective thins the possibility of training eclectic and versatile young workers in the same way as the National Curriculum Parameters. Despite the recognition of the legitimacy of school subjects with their languages and epistemologies, knowledge needs to be integrated so that young people can understand contemporary problems.

Analysing some textbooks, it is possible to observe that the school knowledge in the perspective of interdisciplinarity is more evident in textbooks of the Languages and Human Sciences areas. This is not an exclusively epistemological issue; but rather something inherent in the dynamics of disciplinary communities (Goodson, 1997). Such communities move mainly in view of their cultural and belonging issues, which favours (or not) certain articulations. School subjects such as History and Geography, for example, seem to have already elaborated their issues around the interdisciplinarity theme. In this way, the didactic books develop didactic-pedagogical proposals that consider in different intensities the possibility of interdisciplinary approaches.

In all areas, the textbooks evaluated in the PNLD present the possibility of approaching school knowledge in the perspective of interdisciplinarity, always as a kind of complement. The didactic units—be they thematic blocks or chapters—always begin within a disciplinary field, even if it is only for contextualization. They present interdisciplinarity as a possibility to complement concepts developed in teaching, often offering suggestions for projects or other forms of interaction between disciplines in the final sections of the chapters. This pattern may further hinder the development of interdisciplinary teaching processes, since the integration proposals are not constitutive of the didactic pedagogical core of school knowledge. 


\section{pro.posıções}

$e$-ISSN 1980-6248

http://dx.doi.org/10.1590/1980-6248-2016-0052

\section{The narratives of working lives: classroom scenes-the fourth site}

We have chosen to present the professional life narratives of two teachers from different generations: one who entered the profession in the 1990s, and another who is just beginning. Their narratives are presented as monads, fragments of life histories taken from interviews conducted with these professionals. These monads were inspired by Walter Benjamin's thought and his concepts of memory and history (Benjamin, 1994; Petrucci-Rosa, Ramos, Correa, \& Almeida Jr., 2011). Petrucci-Rosa et al. (2011) regard the monad as a key to maintaining the balance between an idiosyncratic and hermetic individualism, which does not communicate with the outside world, and an illusory social conscience that aims to encompass the subjects ignoring their specificities. In this sense, the monad can reveal the unique character of the educational experience, without losing sight of its articulations both with the vast universe of the culture in which it is immersed, as well as with the subjective gaze of the researcher.

Studying life histories, we point out the importance of considering the thematic density present in the interviews which were conducted with these professionals (Goodson, 2013). To refine this subject's field and focus on selected aspects of research, Goodson proposes drawing "portraits" that provide the profile, traits and sensibilities of the life histories one intends to study about.

Life history interviews provide a wealth of data. ... A large data bank of interview transcripts can be generated in this way and the process of analysing these data is inevitably painstaking and complicated. (Goodson, 2013, p. 40)

As themes emerge from the detail of life history interviews, it becomes clear that some life storytellers cover many of the relevant themes, whilst others may only contain evidence of a small number of issues or may cover the themes superficially or rapidly. I use the phrase 'thematic density' to characterize those life history interviews that either cover a wide range of themes or cover particular themes in broad and profound ways.

Having then identified the major themes at work in life narratives, and having begun to employ some of these themes to conceptualize narrative character, a new stage of work can be undertaken. In many of the research studies I have been involved in, I have advocated and employed the development of detailed personal case studies or 'portrayals of the most thematically dense' life histories. (Goodson, 2013, pp. 40-41) 


\section{pro.posıções}

$e$-ISSN 1980-6248

http://dx.doi.org/10.1590/1980-6248-2016-0052

In this paper, we have selected histories of the professional lives of two high school teachers and have developed their portraits with a single focus: the journey of school knowledge. Thus, we will not present other aspects from the rich thematic density afforded by their interviews. In other words, we will present two portraits consisting of a particular set of monads produced from the interviews with the two teachers. Marina is an experienced teacher who has started working in the public school 20 years ago, and Liz is a beginning teacher who was in her training period when she was interviewed.

\section{Portrait of Marina, an experienced teacher of biology}

\section{Monad M1}

\section{Completely different}

It was completely different to be a biology teacher 18 years ago. I entered the classroom and saw the students' posture and alignment and their tables were well organised in rows. They had textbooks and followed a script. I could come in the classroom and spend the first day of school talking about all that they would do for the full year including their assessments. They were all very organised, and you could even teach. The parental involvement was entirely different from today.

\section{Monad M2}

\section{Entirely expository}

The lessons were entirely descriptive, and I began to work with slides. Sometimes, I could take the students to the lab if some material was available such as microscope slides. However, most of the time, the lessons were a comprehensive exhibition. They studied the concepts in the textbook, and they saw pictures in them. I was satisfied with this kind of lesson. 


\section{pro.posições}

$e$-ISSN 1980-6248

http://dx.doi.org/10.1590/1980-6248-2016-0052

\section{Monad M3}

\section{I didn't know how to do it!}

I had participated in some interdisciplinary projects, but they did not work because we did not know how to do them! I did not know how to do it and ended without any result! We are currently trying to guide what we will do during the next year. In the private schools, we are already working this way. There are projects, environmental studies, in which teachers give students activities related to the topic of interest. They have to connect and interact the original activity with other subjects, e.g. relate History with Biology, Mathematics, or Portuguese.

\section{Portrait of Liz - beginning teacher of History}

\section{Monad Ll}

\section{Street poster}

Articulating four subjects: History, Philosophy, Sociology and Geography. Despite their similarity, this is difficult. We were in the training stage, and this is the first two weeks of observations. Thus, we were worried about a particular theme for our project. Some ideas have been raised-broad themes that we could refine-but what worked was a proposal first called a "street poster". We aimed to promote the students' awareness of the means they had for expressing their desires and anxieties via this intervention. For this, we first thought to create a street poster because this is a common manifestation of society. It is easy to grasp and reproduce. They could make use of graffiti, commercials, and advertisements in magazines as well. I found some difficulties the first time I had to write about the project. This task is a broad topic, and each student has different backgrounds. Thus, we thought of various proposals. In the beginning, we thought it would be interesting to carry out the project in the form of a discussion with students sitting in a circle rather than the traditional model. I believe that there were two main reasons. The first is that we could not split the subjects-nor was it 


\section{pro.posıções}

$e$-ISSN 1980-6248

http://dx.doi.org/10.1590/1980-6248-2016-0052

our intention. The second was that our goal was to talk and encourage several expressions. Thus, it would be inconsistent for them to watch our lessons quietly.

\section{Monad L2}

\section{Different ways to tell history}

I wanted to present, to the students, the idea that there is more than one way to tell history. I believe that the vast majority of people are used to thinking about history in only one way: written. Oral history is a powerful alternative. Thus, the first images of my class would be famous pictures of photojournalism. Through the displayed images, we invited them to try to recreate the stories and to realise that there are also documents and imagery and that they also have intentions. To better show the discourses behind the images, we selected two conflicting groups - each with three photos. The first one was three pictures by photographer Apu Gomes recording violence against police officers in São Paulo in 2006. The images showed the devastated city taken by fear and burned buses. The second group contained a set of photos called Marginália by John Wainer, who portrays the daily life of the slums in São Paulo and Rio de Janeiro- two portraits of those living on the margins of society. We selected some World War II advertisements that showed ads for women. They were very different in Germany and the United States. In one, healthy women were encouraged to procreate, and in the other, women were called to work. Two conflicting discourses taking place in the same period but in different locations.

\section{Monad L3}

\section{Valid and pleasurable experience}

We had assembled the class in the schoolyard, and we sat at several long tables. We came around helping and giving advice when required. In the end, we left quite satisfied. I believe the initial design ( 2.5 weeks) was important to deepen the discussions. I think that the class would welcome the opportunity to discuss it more, but the short time we were given was used well by everyone. It was a valid and pleasurable experience. 


\section{pro.posıções}

$e$-ISSN 1980-6248

http://dx.doi.org/10.1590/1980-6248-2016-0052

The monads show the importance of learning in teacher education, which is dedicated to the development of a significant narrative capital for the redefinition of the professional teaching culture (Goodson, 2013, 2014). This narrative learning takes place in the lives of teachers crossed by school experiences. The fragmented histories quoted here from the narratives of two high school teachers from different generations were chosen with a thematic focus. Such a focus is associated with our need to understand the journey of school knowledge, demanded by the interdisciplinary nature of the secondary education policies developed in the last fifteen years in Brazil. We can call the two sets of monads "portraits" because they offer elements of the life histories of these professionals as linked by their experiences and their cultural background.

Marina is a teacher trained in the 90 s and invested in setting up a teaching identity characterised by the idea that planning and control are essential elements of pedagogy. All her efforts are focused on improving practices including learning about the rationalisation of teaching.

In this sense, the systemic narrative present in curriculum documents about school knowledge addressed in an interdisciplinary way suffers a refraction in Marina's professional life history. For her, it is difficult to think about the production of school knowledge, giving up control in the classroom, and planning lectures. Interdisciplinary practices require much more effort and energy and might be seen as something new and troubled in her professional life.

The beginning History teacher, Liz, recounts experiences with interdisciplinary practices during her training process. Liz is aware that school knowledge is in constant tension, and this is acknowledged by the disciplinary origin. By facing the challenges of participating in an interdisciplinary project in high school, Liz points out the importance of giving up control in the classroom. This challenge is what drives the possibility of dialogue between disciplines. This aspect of Liz's narrative reminds us of Basil Bernstein (1971) when he discusses concepts of integrated curriculum, framing, and control. For this author, a more classified curriculum makes school subjects more isolated and stronger in framing the pedagogical practices. Framing is related to the forms of control that teachers have over their students and the teaching plan. Integrated codes favour horizontal relations at all levels 


\section{pro.posıções}

$e$-ISSN 1980-6248

http://dx.doi.org/10.1590/1980-6248-2016-0052

between educators and students. For Liz, power relations have weakened her classroom framing. This assumption was quite productive in her interdisciplinary practices.

This situation can also be considered a type of refraction in the long journey of school knowledge. Each particular classroom will produce their forms of integration, dialogue, and production. If the curriculum documents establish boundaries for the production of school knowledge, then interdisciplinarity in the classroom can break them, leading teachers and students to learn from their narratives.

The refractive processes present in the production of school knowledge are not "system defects" but creative forms of resistance and survival that make the school a reframing space in people's lives.

It is important to consider the political and cultural dimension of the school's role in the contemporary world as it breaks with a conventional curriculum notion which does not consider people's lives. This crisis is already underway. Therefore, narrative learning can be way out.

In the new social future, we must hope that curriculum will engage with the life missions, passions, and purposes that people articulate in their lives. Now that would truly be a curriculum for empowerment. Moving from authoritative prescription and primary learning to narrative empowerment and tertiary learning would transform our educational institutions and make them out their early promise to help in changing their students' social future. (Goodson, 2014, p. 164)

What the refraction process warns us of is the 'unintended consequences' of symbolic changes and initiatives at the government level. What sets out as being a reform with clear intentions and objectives is actively re-interpreted and re-directed at each stage of refraction. On the "long journey" of school knowledge the only way to understand these reinterpretations is to show sensitivity and sympathy to the life missions and intentions of the social actors involved at each refractive stage. Without this narrative knowledge and narrative learning, government intentions can have grievously count-productive results. It is time, therefore, to broaden the scope of policymaking. 


\section{pro.posıções}

$e$-ISSN 1980-6248

http://dx.doi.org/10.1590/1980-6248-2016-0052

\section{The refraction into the journey of knowledge}

When considering the journey of school knowledge from the establishment of official curricular policies until their arrival in the classrooms, the starting point is the school knowledge. Didactic processes are undertaken so that knowledge becomes teachable, also contributing to the establishment of traditions in the school culture, organizing this knowledge in disciplines.

The point of arrival of the journey is the classroom, which we try to understand here based on the histories of the two high school teachers who narrated their experiences concerning school knowledge. Between the points of departure and arrival, we observe a process of refraction, through the perspective of periodisation as proposed in Goodson and Lindblad (2010) and Goodson (2014), attained by listening to teaching narratives from at least two generations of teachers.

The actors involved in the process are not passive, and reinterpret the political intentions coming from the macro level. The elucidation of individual narratives may indicate how the actors mean their own lives and their professional practices. These data offer examples of various practices and their underlying factors.

The portraits we have presented provide us with "little tales" of conviction and transgression, of innovation and conformity, of conformity and resistance, and, in considering them in a broader socio-historical context along with the waves of reform, they can provide descriptions of the extent to and the ways in which ideology and power reformulate the educational landscape, influencing and shaping everyday practice (Rudd \& Goodson, 2016).

At this point of the journey, it is important to indicate the processes of refraction that occurred during the passage through each site; from the macro level of the curricular policy to the micro, represented by the teachers' histories.

In the second site, school knowledge undergoes its first bending: school subjects, although still respected, are challenged to mobilise themselves in interdisciplinary practices. In the curriculum documents produced in the last two decades, the demands for an eclectic, versatile and generalist young worker emerged in the systemic narratives and provoked 


\section{pro.posıções}

$e$-ISSN 1980-6248

http://dx.doi.org/10.1590/1980-6248-2016-0052

destabilizing effects of the disciplinary field as the domain of specialists who by themselves would deal with school knowledge.

In curricular documents such as DCNEM (Brasil, 1998), PCNEM (Brasil, 2000), OCEM (Brasil, 2006), and DCNEM (Brasil, 2012) there is a recurrent narrative that denies a break with the disciplinary boundaries, but which, on the other hand, indicates the need for a dialogue between school subjects in order to comprehend more comprehensively the social, scientific and technological reality.

However, it is also important to highlight that the perspective of interdisciplinarity narrated in such documents is given, first and foremost, by combining two or three school subjects around specific themes: without the signalling of broader plans that are constitutive of the pedagogical political project of the school. In these documents, for most school subjects, the already established knowledge is thematically approximated creating points of intersection in which some common teaching becomes possible. The interdisciplinary question is discussed as a little didactic resource, not as a possibility of producing scholarly knowledge in the collective sphere.

Between the second and third sites, there are no significant points of flexion: the potential of interdisciplinary practices continue to be indicated, predominantly, as educational resources; as accessories to the units of instruction developed in textbooks and with particular character, combining, in most cases, the school subject "pair by pair".

The most intense refraction occurs even as we enter the high school teachers' histories. Marina narrates the difficulties of considering the implementation of interdisciplinary practices in the school. In general, teachers have a very intense weekly workload within the classroom, and this, among other factors, makes it difficult to establish a work agenda that is organised around interdisciplinary projects. Liz narrates the interdisciplinary practices that she experienced in her teaching initiation, valuing the complexity of undertaking a collective work, the need for joint planning and the availability to deal with students' questions, aspects that are not considered in the curricular documents.

In general terms, periodisation has shown that beginning teachers do not seem to demonstrate significant resistance to systemic narratives regarding interdisciplinarity in High School. They appear to be enchanted by the possibilities of dialogue, of a reorganisation of 


\section{pro.posıções}

$e$-ISSN 1980-6248

http://dx.doi.org/10.1590/1980-6248-2016-0052

pedagogical work and interventions considered by them as innovators. However, in these narratives, the perception appears that perhaps "in the school itself, it is not possible to do so". The difficulties demonstrated by both the experienced teacher and the beginner, lead us to defend a radical reform in schools, deconstructing spaces and times. Curriculum policymakers need to take into account that narratives that oscillate between interdisciplinarity and polyvalence are not promising for the production of this powerful knowledge in school. The specificities of the academic fields, be they scientific, literary or artistic, are the elements that will bring young people the re-reading of their daily life. Teachers will always play a significant role in producing this knowledge. On the other hand, even considering the importance of teaching disciplinary training, it is necessary to break with a highly classified and framed curriculum. High School, as well as the final years of Elementary School, are traditionally instituted in the daily life of the school with classes lasting between 45 and 50 minutes, assigned to different school subjects. This disciplinary organisation is the most powerful symbolic mark of the curriculum blending because, from time to time, classes from different school subjects are developed.

In the institutionalisation of an interdisciplinary High School, the timetable could be more mobile and planned concerning the interdisciplinary projects proposed by the school collective in the context of the pedagogical political project of the school. For this, the times would be organised not as disciplines, but for work tasks planned for the production of interdisciplinary scholarly knowledge. Teachers from different school subjects would form work teams with the students, establishing guidelines, agendas and routines from which the questions elaborated in the projects could be understood concerning the specialised knowledge that each field can offer.

In this sense, the timetable could be organised in relation to the projects, rather than the school subjects, foreseeing joint actions with different teachers that would coordinate meetings with students not alone, but in partnership with colleagues. According to the proposal here, it is also important to highlight changes in the work contract of teachers who, assuming 40 hours a week, would have to preserve at least 8 hours per week for the planning, development and evaluation of interdisciplinary projects with their peers, the teachers in the school culture. 


\section{pro.posıções}

$e$-ISSN 1980-6248

http://dx.doi.org/10.1590/1980-6248-2016-0052

\section{References}

Benjamin, W. (1994). Magia e técnica, arte e política: ensaios sobre literatura e história da cultura/Walter Benjamin (7a ed.). São Paulo: Brasiliense.

Bernstein, B. (1971). Class, codes and control: theoretical studies towards Sociology of Language. London: Routledge \& Kegan Paul.

Brasil (1998). Diretrizes Curriculares Nacionais para o Ensino Médio. Conselho Nacional de Educação (CNE). Resolução n. 3, de 26 de junho de 1998. Diário Oficial da República Federativa do Brasil, Brasília, DF.

Brasil (2000). Parâmetros Curriculares Nacionais para o Ensino Médio (Bases Legais). Ministério da Educação: Secretaria de Ensino Médio, 2000.

Brasil (2006). Orientações Curriculares Nacionais para Ensino Médio. Ministério da Educação: Secretaria de Ensino Médio, 2006.

Brasil (2015). Programa Nacional do Livro Didático. Edital de Convocação 01/2013 CGPLI. Edital de Convocação para o Processo de Inscrição e Avaliação de Obras Didáticas. Brasília: MEC/FNDE. Retrieved January 16, 2018 from http://www.fnde.gov.br/programas/programas-do-livro/legislacao/item/9787-sobreos-programas-do-livro12

Goodson, I. F. (1983). School subjects and curriculum change: case studies in curriculum history. Londres; Canberra: Croom Helm.

Goodson, I. F. (1997). A construção social do currículo. Lisboa: EDUCA.

Goodson, I. F. (2001). O currículo em mudança. Porto: Porto Editora.

Goodson, I. F. (2013). Developing narrative theory - Life histories and personal representation. New York: Routledge.

Goodson, I. F. (2014). Curriculum, personal narrative and the social future. New York: Routledge.

Goodson, I. F., \& Lindblad, S. (2010). Professional knowledge and educational restructuring in Europe. Rotterdam/Boston/Taipei: Sense Publishers. 


\section{pro.posıções}

$e$-ISSN 1980-6248

Goodson, I. F., \& Rudd, T. (2012). Developing a Concept of Refraction: Exploring Educational Change and Oppositional Practice. Educational Practice and Theory, 34 (1).

Hobsbawn, E. (1994). The age of extremes - The short twentieth century: 1914-1991. Londres: Michael Joseph.

Lindblad, S., \& Goodson, I. (2011). Researching the teaching profession under restructuring. In I. F. Goodson, \& S. Lindblad (Orgs.), Professional knowledge and educational restructuring in Europe. The Netherlands: Sense Publishers.

Lopes, A. C. (2004, maio/junho/julho/agosto). Políticas curriculares: continuidade ou mudança de rumos? Revista Brasileira de Educação, 26, 109-118.

Moreira, A. F. B., \& Ferreira, M. S. (2001). A história da disciplina escolar ciências nas dissertaçooes e teses brasileiras no período 1981-1995. Ensaio: pesquisa em educação em ciências, 3(2), 133-144.

Petrucci-Rosa, M. I, Ramos, T. A., Correa, B., \& Almeida Jr., A. S. (2011, janeiro/junho). Narrativas e mônadas: potencialidades para uma outra compreensão de currículo. Currículo Sem Fronteiras, 11(1),198-217.

Rudd, T., \& Goodson, I. F. (2014). Studying historical periodisation: Towards a concept of refraction. In A. Teodoro, \& M. Guilherme, European and Latin American higher education between mirrors: conceptual frameworks and policies of equity and social cohesion, 139-154.

Rudd, T., \& Goodson, I. F. (2016, janeiro/abril). Refraction as a tool for understanding action and educational orthodoxy and transgression. Tempos e Espaços em Educação, 9, 99110.

Zotti, S. A. (2004). Sociedade, educação e currículo no Brasil: dos jesuítas aos anos 1980. Campinas: Editores Associados; Brasília: Plano. 


\section{pro.posıções}

$e$-ISSN 1980-6248

http://dx.doi.org/10.1590/1980-6248-2016-0052

\section{Legislação}

Lei BR no 9.394, de 20 de dezembro de 1996. (1996). Estabelece as diretrizes e bases da educação nacional. Diário Oficial da União. Brasília: Presidência da República. Casa Civil. Subchefia para Assuntos Jurídicos.

Submetido à avaliação em 10 de março de 2017, revisado em 24 de outubro de 2017, aceito para publicação em 24 de novembro de 2017. 